UNITED STATES

DEPARTMENT OF THE INTERIOR

GEOLOGICAL SURVEY

FILLING OF SPIRIT LAKE, WASHINGTON,

MAY 18, 1980, TO JULY 31,1982

By William Meyer and Philip J. Carpenter

U.S. GEOLOGICAL SURVEY

OPEN-FILE REPORT 82-771

Tacoma, Washington

1983 
UNITED STATES DEPARTMENT OF THE INTERIOR

JAMES G. WATT, Secretary

GEOLOGICAL SURVEY

Dallas L. Peck, Director

For additional information write to:

District Chief

U.S. Geological Survey

1201 Pacific Avenue - Suite 600

Tacoma, Washington 98402-4384
Copies of this report can be purchased from:

Open-File Services Section Western Distribution Branch U.S. Geological Survey Box 25425, Federal Center Lakewood, Colorado 80225

(Telephone: (303) 234-5888) 
CONTENTS

Page

Abstract-_- 1

In troduct ion--

Hydrologic changes imposed by the May 18, 1980, eruption-_-_-_-_-_ 6

Observed lake filling-_- 11

Average annual and winter change in lake volume-12

Change in lake volume for selected time periods-_._._. 16

Projected lake filling- 17

References-_- 19

\section{ILLUSTRATIONS}

Figure 1. Map showing location of the study area- 3

2. Graph showing Spirit Lake volume versus $t$ ime, May 21,1980 , to August 1,1982 , and projected volumes for selected precipitation rates- 4

3a. Bathymetric map of Spirit Lake before the May 18, 1980, eruption of Mount St. Helens- 7

3b. Bathymetric map of Spirit Lake after the May 18, 1980, eruption of Mount St. Helens-_ 8

4. Map showing thickness of the debris blocking Spirit Lake- 9

5. Graph showing monthly changes in Spirit Lake volume, June 1980 through July 1982-_ 13

6a. Graph showing relation of lake stage and lake area for Spir it Lake-_-_- 15

6b. Graph showing relation of estimated annual evaporation and area for Spirit Lake-_-

TABLES

Table 1. Monthly change in Spirit Lake volume 


\section{Multiply}

inches (in.) )

feet $(f t)$

miles (mi)

(mis)

square miles $\left(\mathrm{mi}^{2}\right)$

cubic yards $\left(y^{3}\right)$

acres--

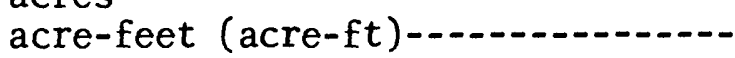

By

25.40

2.540

0.0254

0.3048

1.609

2.590

.7646

4047.

1233.

0.001233
To obtain

millimeters $(\mathrm{mm})$ centimeters $(\mathrm{cm})$ meters (m) meters (m) kilometers $(\mathrm{km})$ square kilometers $\left(\mathrm{km}^{2}\right)$ cubic meters $\left(\mathrm{m}^{3}\right)$ square meters $\left(\mathrm{m}^{2}\right)$ cubic meters $\left(\mathrm{m}^{3}\right)$ cubic hectometers $\left(\mathrm{hm}^{3}\right)$

Tallany, Van Kuren, Gertis, and Thielman Datum of 1981 (TVGT of 1981): Datum derived from reference marks and surveyed at 1-mile intervals by TVGT and from auxiliary elevation control points surveyed by SPAN Interational, Inc. Specified accuracies were third order for reference marks and to 3 feet for auxiliary points. All altitudes in this report are referenced to TVGT. 


\title{
FILLING OF SPIRIT LAKE, WASHINGTON, MAY 18, 1980, TO JULY 31, 1982
}

By William Meyer and Philip J. Carpenter

\begin{abstract}
The rockslide/debris avalanche from the north face of Mount St. Helens that precipitated the volcano's eruption on May 18, 1980, blocked outflow from Spirit Lake, Washington. There has been no surface outflow since that time. From May 21 , 1980, when the first measurement of lake level was made, to August 1, 1982, Spirit Lake has increased its volume from 122,800 acre-feet to 264,000 acre-feet, an increase of 115 percent. Lake level has risen approximately 54 feet during this period.

Hydrologic and geologic properties of the debris dam are unknown, but the materials obviously are easily erodible. Steep-walled channels up to 60 feet deep have been eroded into the dam and are extending headward toward the lowest points on the crest. In addition, it appears that the lower areas on the crest of the dam are underlain by ash cloud deposits of low density. Indications are that the debris dam could fail by headward erosion, by overtopping with rapid downcutting, or by "piping" and rapid erosion. Each type of failure can produce rapid release of stored lake water with very high discharge rates.

On the basis of observed filling rates of the lake over the last 2 years and precipitation records at four long-term, low altitude National Weather Service stations, it is expected that normal precipitation will fill the lake to the dam crest in December 1985. This estimate is also based on the assumption that loss of water from the lake by seepage continues at the present rate until December 1985. With normal precipitation during the coming year (August 1982 through July 1983) the lake will fill to a level 50 feet below the lowest existing point on the crest of the debris dam, which is at 3,532 feet altitude.
\end{abstract}

If precipitation exceeds normal by 1.5 times during this coming year, the lake level will be 40 feet below the 3,532 -foot crest of the debris dam by the end of July 1983.

This same lake level can be reached by the end of March 1983 if precipitation from October through March is twice the winter mean. 


\section{INTRODUCTION}

The eruption of Mount St. Helens on May 18,1980, resulted in the deposition of approximately 4 billion cubic yards of material in the upper 16 miles of the $N$ orth Fork Toutle River valley (fig. 1). This material, derived mainly from the rockslide/debris avalanche from the mountain's north face, filled the upper 16 miles of the valley across its entire width, blocking tributary inflow to the North Fork Toutle River and blocking the outflow of Spirit Lake. Thickness of this material varies greatly, and reaches a maximum depth of approximately 520 feet in the vicinity of Spirit Lake.

Following the eruption, the U.S. Geological Survey began systematic monitoring of the level and volume of Spirit Lake. An initial assessment of the stability of the debris dam blocking the lake was made by Youd, Wilson, and Schuster (1981). These authors concluded that "the blockage (debris dam) is stable against slope failure due to gravitational or earthquake forces, and that it should resist piping failure both under 1980 and probably future hydrologic conditions." They also concluded that further study was needed to determine the possibility of overtopping and its consequences.

Although lake volume decreased during the first 2 or 3 months after the eruption and has remained unchanged for short periods of time since then, the overall trend has been one of increasing its volume (fig. 2). At the present time (August 1, 1982), lake volume is 264,600 acre-feet, an increase of 2.15 times its volume of 122,800 acre-feet, determined for May 21, 1980. Lake level has risen approximately 54 feet during this same period, from 3,404 to 3,458 feet altitude.

The lowest point on the crest of the Spirit Lake debris dam is 3,532 feet, which is 74 feet above the present lake stage. Should the lake fill to this level, it would have a surface area of approximately 3,520 acres, a maximum depth of approximately 225 feet, and a volume of 501,000 acre-feet.

Field observations by the authors indicate that the debris avalanche deposits in the North Fork Toutle River valley are susceptible to rapid erosion, and a concern exists that, should Spirit Lake fill to its maximum volume and overtop its debris dam, rapid downcutting could occur on the dam, releasing a large volume of water from the lake in a short period. The exit path for Spirit Lake is underlain by ash cloud deposits that are apparently more susceptible to erosion than the debris avalanche deposits. Steep-walled channels up to 60 feet deep have been eroded into the ash cloud deposits since the eruption and are extending headward toward the crest of the debris dam. This headward cutting could lower the outlet altitude of Spirit Lake, thereby reducing available time for remedial measures concerning lake overtopping. 


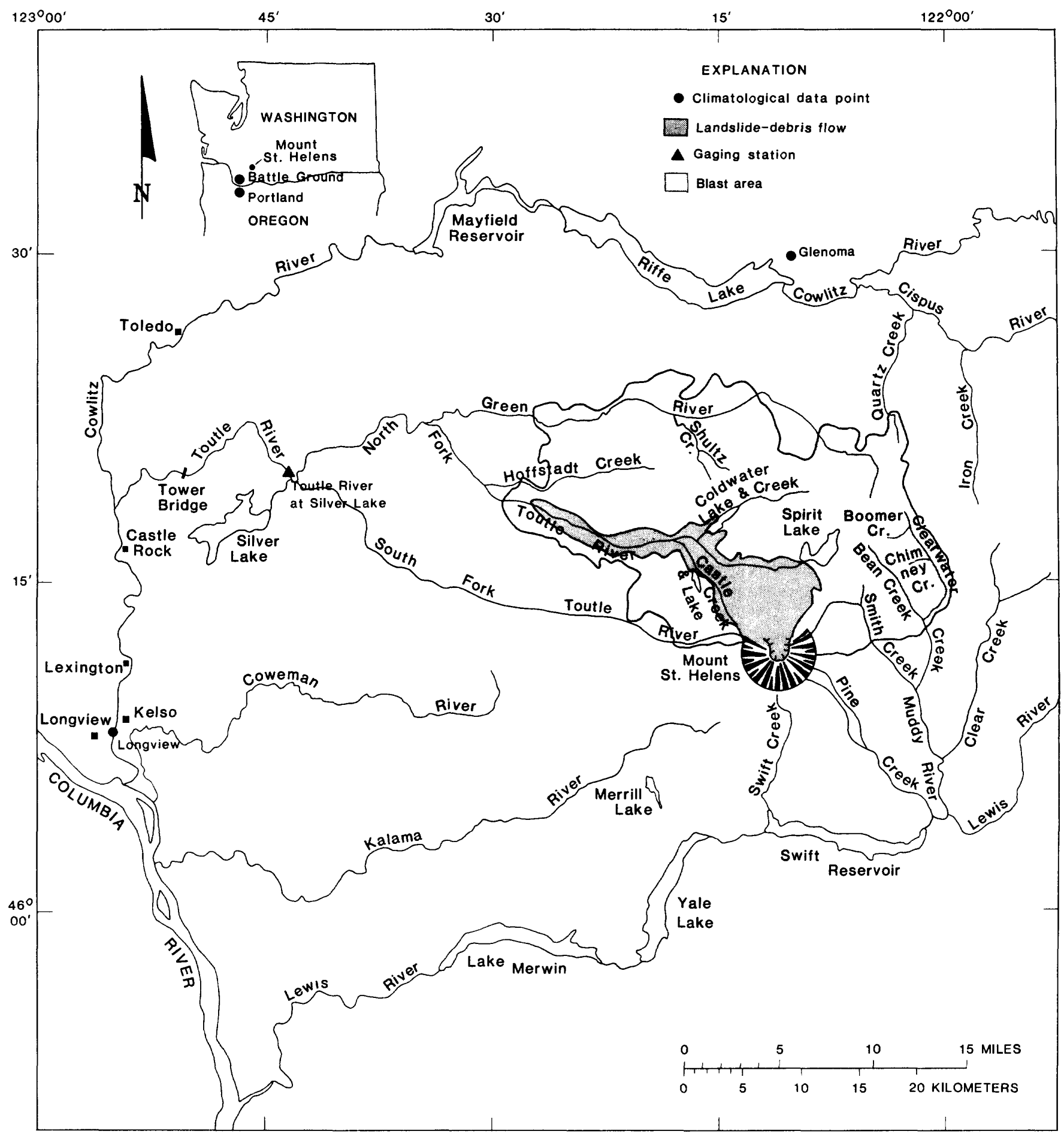

FIGURE 1.--Location of the study area. 


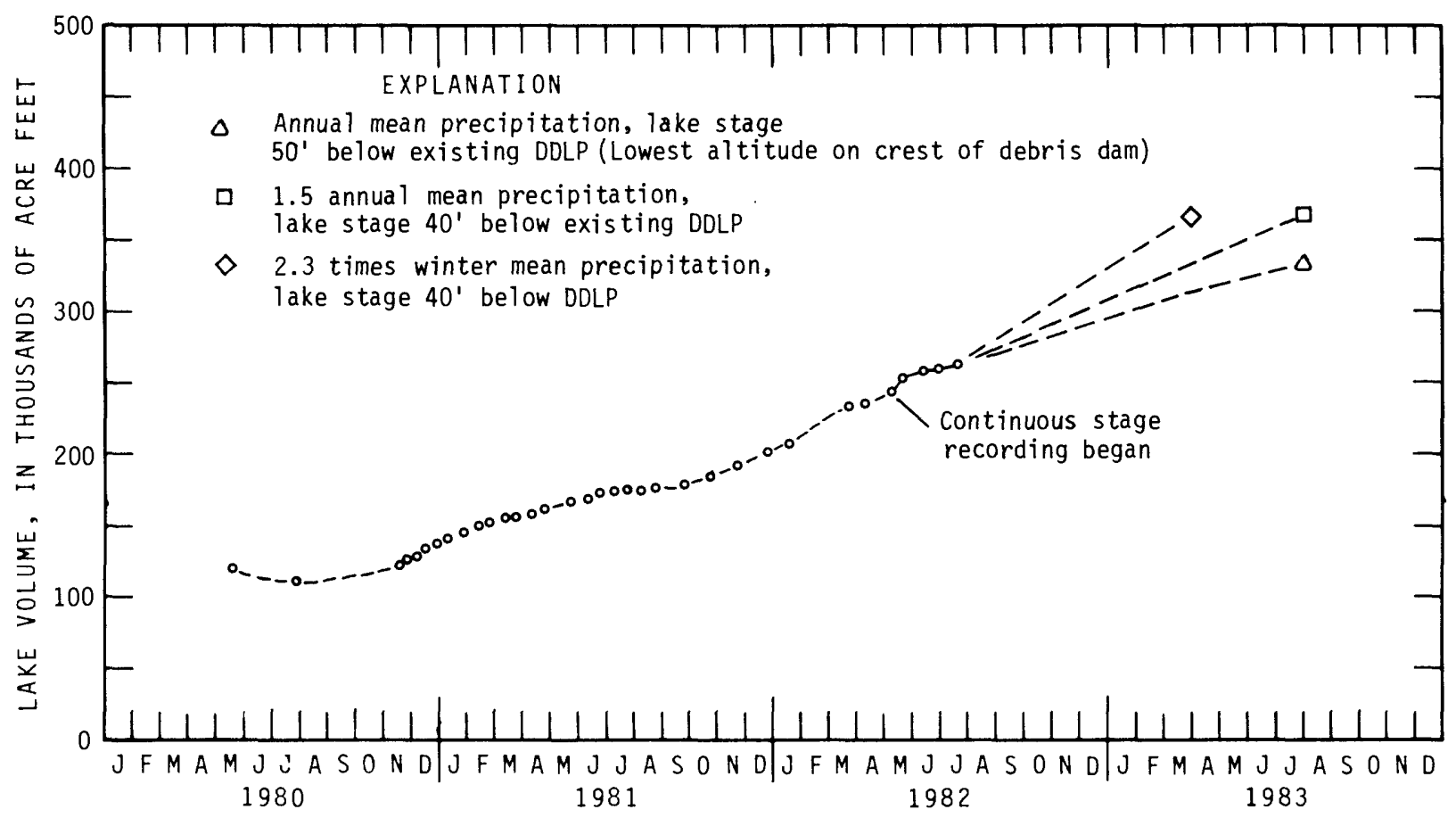

FIGURE 2.--Spirit Lake volume versus time, May 21,1980 , to August 1, 1982, and projected volume for selected precipitation rates. 
Another concern is the stability and water-retarding capabilities of the ash cloud deposits on the crest of the debris dam. This low-density, fine-grained material may be susceptible to "piping," the process which forms a subsurface conduit through the debris. As water flows through the debris it erodes a larger and larger conduit until overhead materials collapse, forming a dam breach. This type of failure may occur rapidly and could release stored lake water at high discharge rates.

This report discusses the rates at which the lake has filled since the May 18, 1980, eruption and, to the extent that available data allow, the magnitude of those processes affecting lake filling. The approximate time at which the lake will fill to its maximum level and volume is discussed. The report does not consider the physical stability of the debris dam, piping, liquefaction, or other possible forms of debris dam failures. 
Some of the immediate hydrologic changes to Spirit Lake and its watershed caused by the events associated with the May 18, 1980, eruption include the following:

* A 206-foot increase in lake level

* Deposition of approximately 350,000 acre-feet of avalanche and eruptive material in the lake

* A decrease in lake volume by approximately 46,000 acre-feet

* Damming of the lake by avalanche and eruptive material

* Addition of approximately 4.0 square miles of drainage area

* Removal of all vegetation from the lake's watershed

* Deposition of avalanche and (or) eruptive deposits over the lake's entire watershed

* Deposition of downed timber into the lake

* Removal of nearly all of the glaciers and snowfields on the mountain flanks from the lake's watershed

* Changes in the physical, chemical, and biological characteristics of the lake's water

The net effect of these events was an immediate change in the precipitation-runoff relationship for the lake's watershed, a change in the lake's area-volume-level relationship, and a change in the evaporation characteristics of the lake. Changes in the physical, chemical, and biological characteristics of the lake are the subject of another investigation and will not be dicussed further in this report.

Changes in the physical characteristics of the lake resulting from the 1980 eruption are shown in figures $3 a$ and $b$. Figure $3 a$ shows contours of the lake prior to the eruption, and figure $3 \mathrm{~b}$ shows contours of the lake observed during March through May 1981. These changes were caused by the deposition of avalanche and eruptive material in the lake. Figure 4 shows the thickness of the deposited material. Deposition of this material in the lake also accounts for the 206-foot increase in lake level after the eruption.

Loss of lake volume by approximately 46,000 acre-feet during the first several months following the eruption probably resulted from a combination of events, including lake water filling the pore space of the debris deposited in the lake and abnormal evaporation from the extreme temperatures associated with the blast.

Prior to the eruption, an outlet channel existed that flowed from the lake to the North Fork Toutle River and lake level remained basically stable, at an altitude of about 3,198 feet. Deposition of the rockslide/debris avalanche and pyroclastic flow deposits in the valley of the North Fork Toutle River dammed the outlet. The crest of the debris dam is downstream from the original drainage divide of the lake's watershed and the lake's drainage area has increased from 14.9 to 18.9 square miles as a result. All of this additional drainage area is on the flanks of the volcano. 


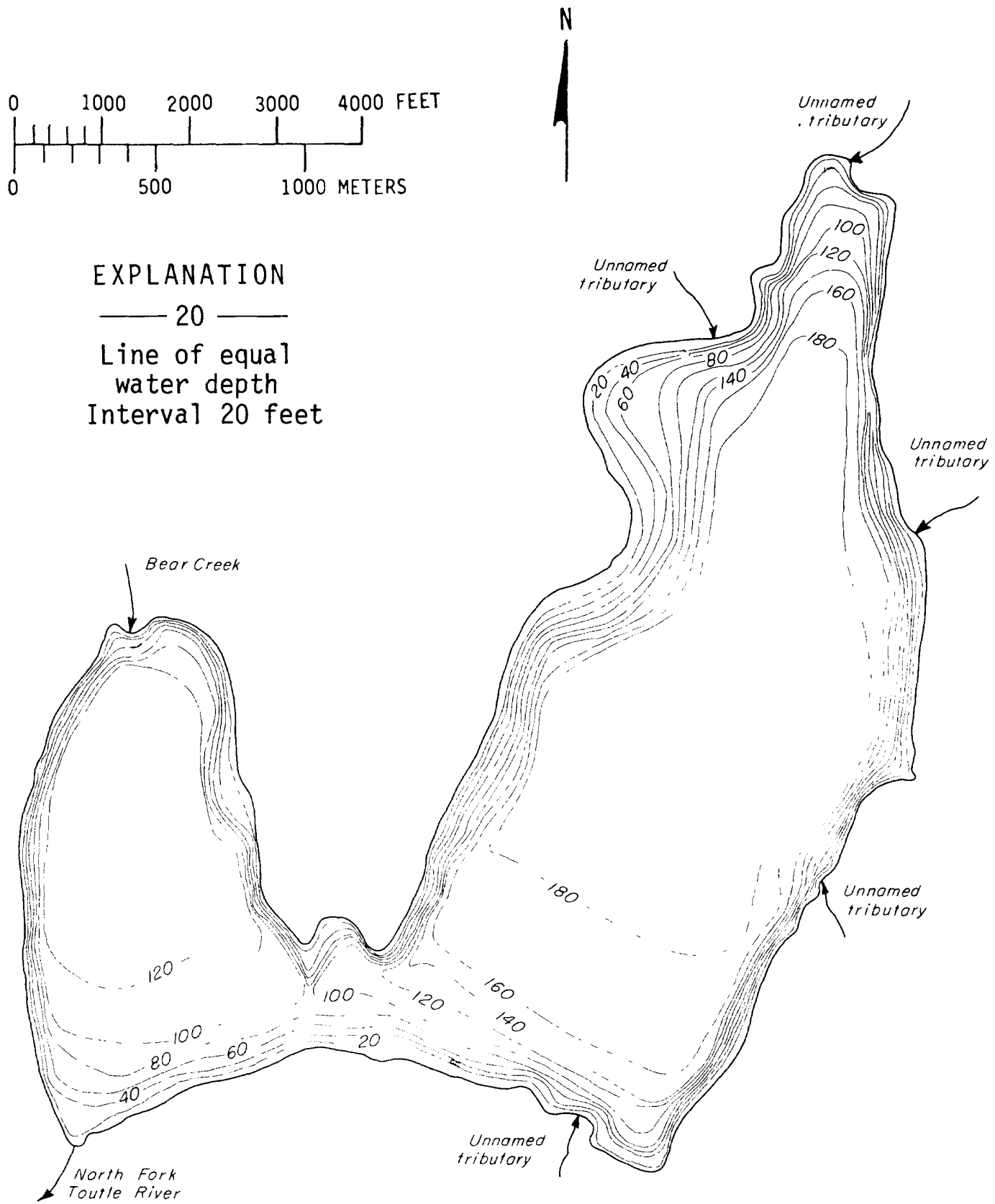

FIGURE 3a.--Bathymetric map of Spirit Lake before the May 18, 1980 , eruption of Mount St. Helens. 

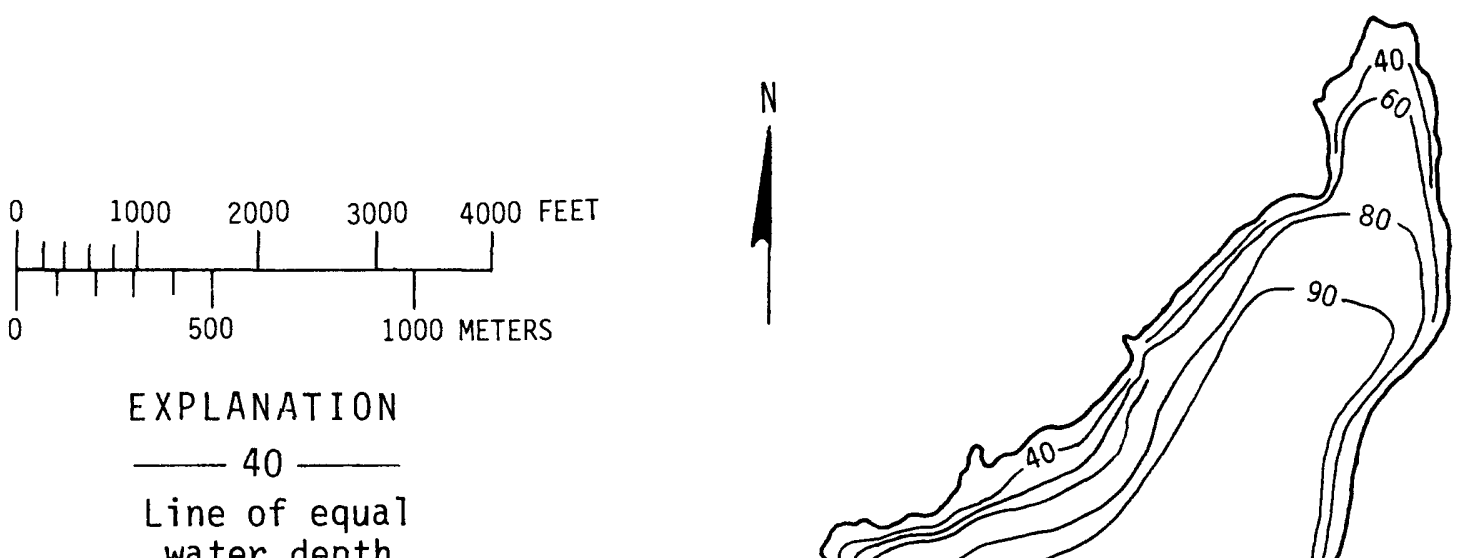

Line of equal water depth

Interval 5, 10 , and 20 feet

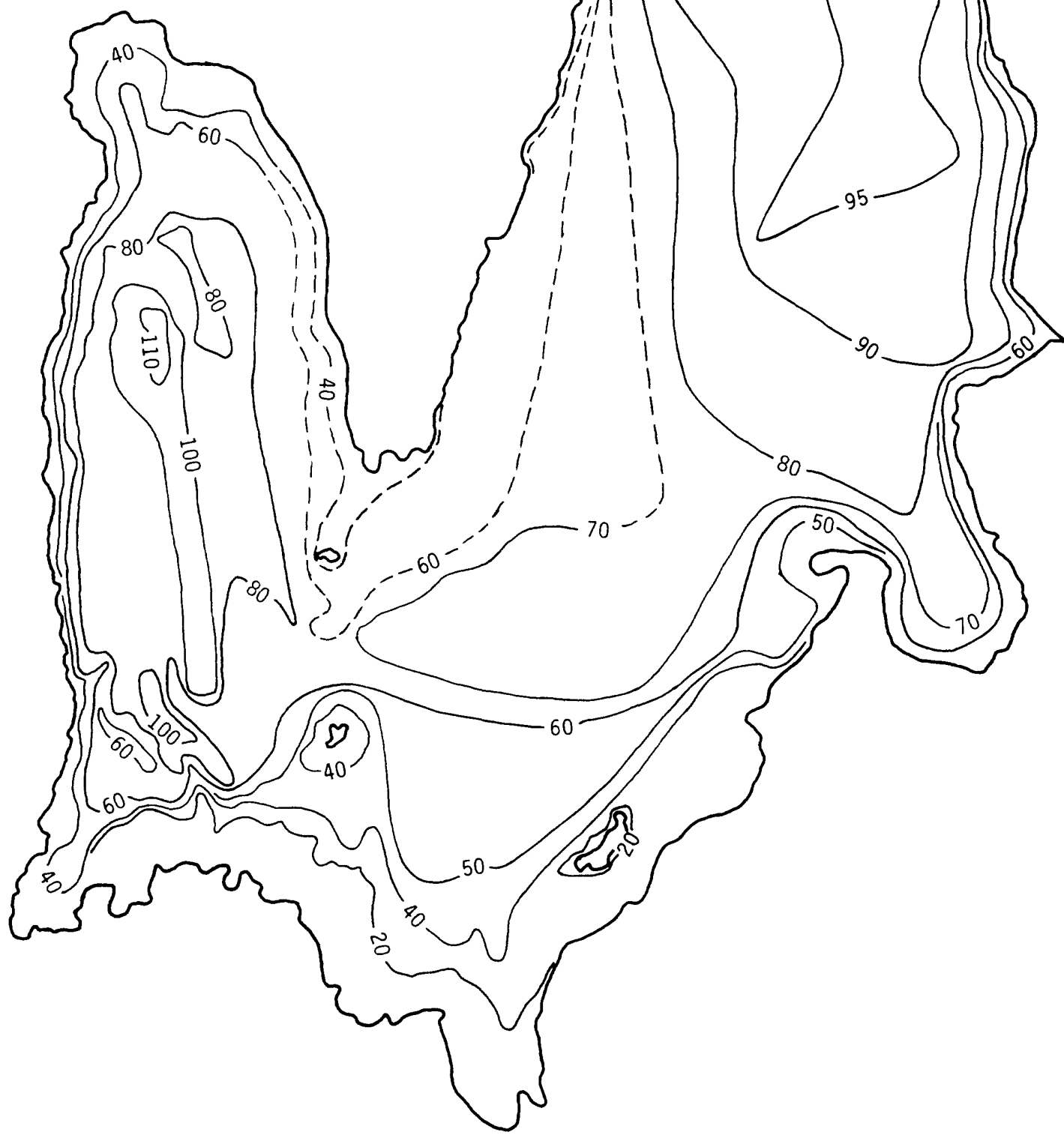

FIGURE 3b.--Bathymetric map of Spirit Lake after the May 18, 1980, eruption of Mount St. Helens. 


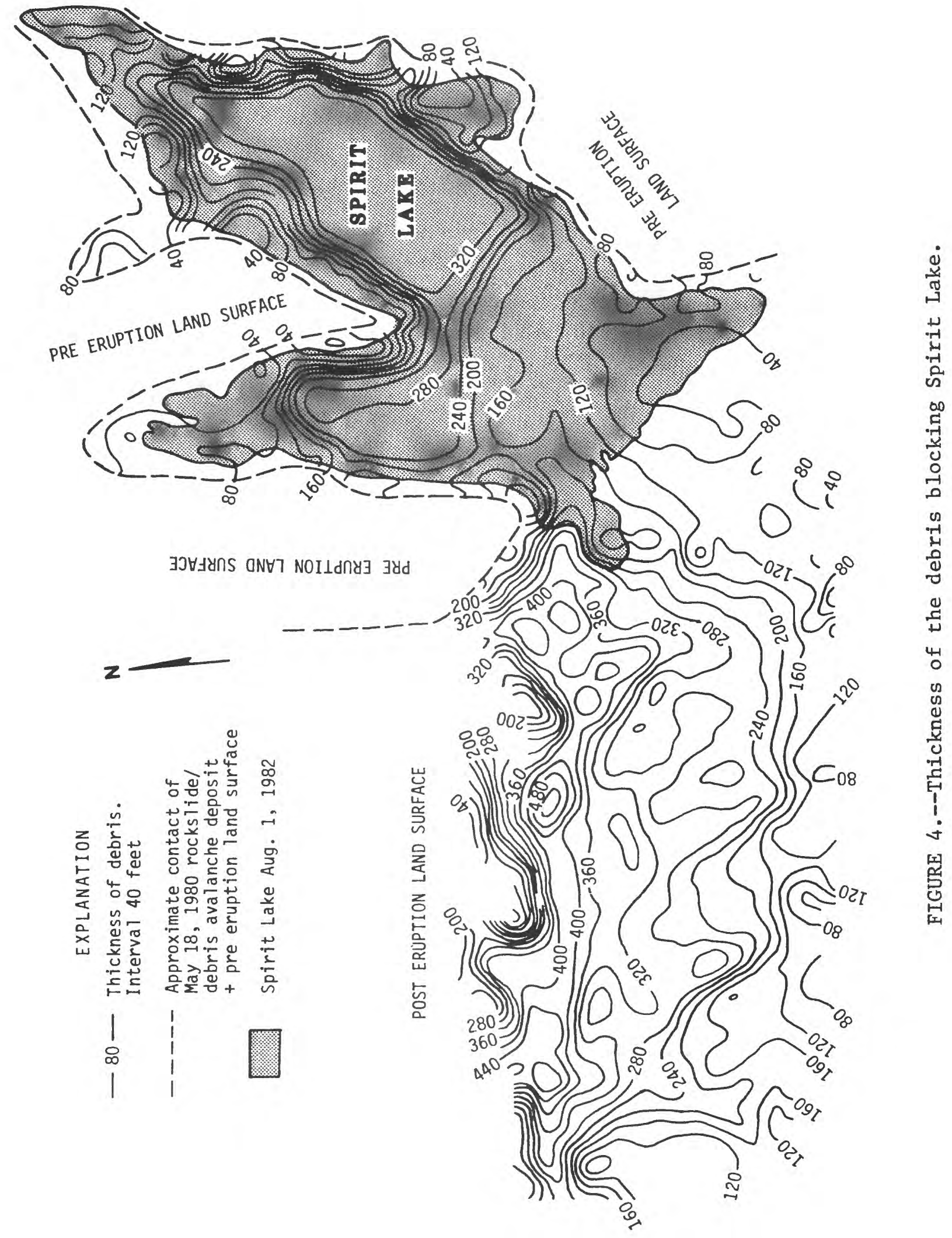


Figure 4 shows that thickness of the debris dam in front of the lake ranges from about 100 to 520 feet. The hydrologic and geologic properties of the debris dam are presently unknown. Geologic mapping of the debris dam is underway, and a drilling program is planned for the near future. Given the source of the deposits and from field observations, it is probably reasonable to assume that the physical characteristics of most of the materials are similar to those determined for the debris avalanche as a whole, (Voight and others, 1981).

The hydrologic system in the Spirit Lake watershed can be assumed to have been in equilibrium on a long-term basis prior to the eruption. The removal of all vegetation from the lake's watershed, deposition of avalanche and (or) eruptive material over the entire watershed, and removal of nearly all the glaciers and snowfields on the mountain's northern flanks from the lake's watershed combined to change the precipitation-runoff relationship in the watershed to an unknown degree. Such factors as interception and transpiration have obviously been reduced to zero, thereby tending to increase runoff for a given amount and duration of precipitation. Removal of vegetation would tend to increase evaporation from the soil and potentially offset reductions in transpiration. Many of the trees were laid horizontally across the hillslopes, and airfall material from the May 18 and subsequent eruptions is trapped behind them. Some overland runoff is temporarily blocked by the trees, providing the opportunity for increased evaporation. Early indications are that ash deposits have reduced infiltration rates (Leavesley, written commun., 1982). Because, on a long-term basis, ground-water outflow from the basin would equal the long-term infiltration to the ground-water system, reduced infiltration would mean that some ground water has drained from storage within the lake's watershed during the last several years. Infiltration rates on the debris in the North Fork Toutle River appear to be relatively high; however, it is probable that ground-water storage is increasing in the debris blocking the lake and in the debris covering the northern flanks of the mountain that are within the Spirit Lake watershed. 


\section{OBSERVED LAKE FILLING}

The filling of Spirit Lake since May 21, 1980, 3 days after the eruption, is shown in figure 2. Periodic observation of water-surface altitude by Geological Survey personnel began May 21,1980, and continued through May 14,1982, when a continuous altitude-recording gage was installed. Lake altitude has been related to volume on the basis of a photogrammetric map of the lake area prepared by the Washington State Department of Transportation for the Geological Survey. Photographs used for this work were obtained December 8, 1980.

As indicated by figure 2 and table 1 , lake volume has increased from 122,800 acre-feet, on May 21, 1980, to 264,600 acre-feet, on August 1, 1982. At maximum volume the present lake would contain 501,000 acre-feet. At the present time (August 1, 1982) the lake volume is approximately 2.15 times that of May 21, 1980, but filling has not continued uninterrupted. Lake volume slightly decreased from May through July 1980, and was basically stable August through mid-September 1981 , a period of no rainfall. At all other times, lake volume has been increasing.

Table 1.--Monthly change in Spirit Lake volume, in acre-feet

\begin{tabular}{|c|c|c|c|c|c|}
\hline \multicolumn{2}{|c|}{1980} & \multicolumn{2}{|c|}{1981} & \multicolumn{2}{|c|}{1982} \\
\hline Month & $\mathrm{v}$ & Month & $\mathrm{v}$ & Month & $\mathrm{v}$ \\
\hline May 18 & $160,000 *$ & January & 4,710 & January & 9,495 \\
\hline May 21 & 122,800 & February & 8,410 & February & 12,835 \\
\hline May 21- & $-7,810$ & March & 3,410 & March & 10,860 \\
\hline June & & April & 7,300 & Apri1 & 6,185 \\
\hline July & $-1,000$ & May & 4,670 & May & 14,210 \\
\hline August & 2,375 & June & 6,220 & June & 7,575 \\
\hline September & 3,600 & July & 1,490 & July & 2,190 \\
\hline October & 3,800 & August & 50 & August & -- \\
\hline November & 4,000 & September & 1,280 & September & -- \\
\hline \multirow[t]{3}{*}{ December } & 12,730 & October & 7,020 & October & -- \\
\hline & & November & 7,245 & November & -- \\
\hline & & December & 8,950 & December & -- \\
\hline
\end{tabular}


Changes in lake volume over a specific time interval, $v / t$, can be expressed by the relationship:

$$
\begin{aligned}
\mathrm{v} / \mathrm{t} & =\mathrm{P}+\mathrm{SM}+\mathrm{GWI} & & \text { Inflow } \\
& -(\mathrm{SA}+\mathrm{ET}+\mathrm{INF}) & & \text { Watershed losses } \\
& -(\mathrm{LE}+\mathrm{LS}) & & \text { Lake losses }
\end{aligned}
$$

where:

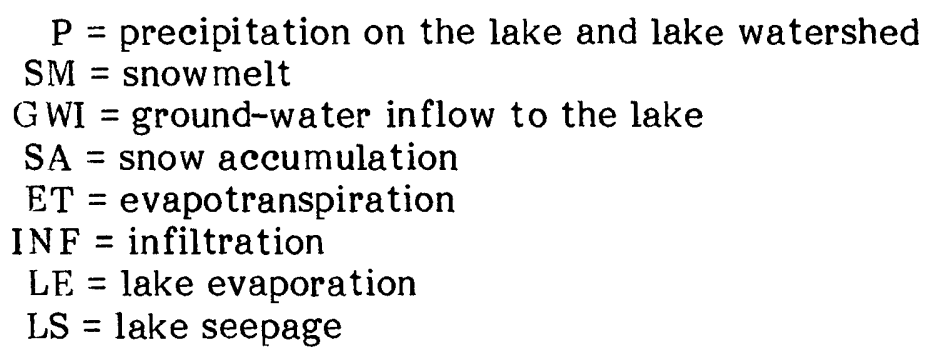

Although some of the above parameters can be measured or approximated reasonably well, others are difficult to define. At the present time only $v / t$, precipitation, and lake evaporation are measured or can be readily estimated.

Monthly changes in the volume of Spirit Lake that have been observed through July 1982 are shown in figure 5 and given in table 1.

Evaluation of precipitation records for long-term National Weather Service Stations at Portland, Oreg., and Battleground, Glenoma, and Longview, Wash., (fig. 1) indicate that between 73 and 75 percent of annual mean precipitation in the area falls between the months October through March, hereinafter referred to as the winter season. These are the nearest long-term stations to Mount St. Helens, and, although they are not necessarily representative of precipitation patterns at Spirit Lake in a strict sense, they should still indicate the general characteristics of precipitation patterns for the area. This suggests that change in lake volume would be greatest during the winter season, unless precipitation is snow that, for the most part, remains unmelted during the winter. Analysis of the change in lake volume for the winter seasons 1980-81 and 1981-82 indicates that 59 percent of the total change observed for August through July occurred in winter the first year and 64 percent the second year. Average percent of winter change in lake volume to annual change for the 2 years was 62 percent. 


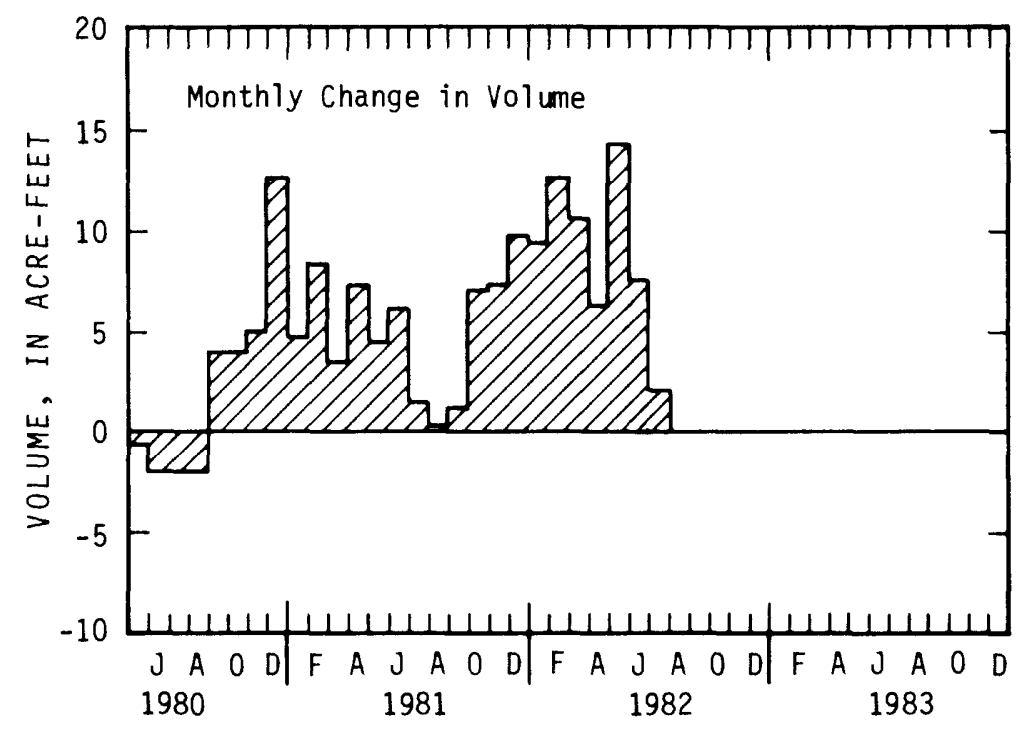

FIGURE 5.--Monthly changes in Spirit Lake volume, June 1980 through July 1982 . 
The Geological Survey maintained a gaging station on the Toutle River just below the junction of the North and South Fork Toutle Rivers. This station, referred to as the Toutle River at Silver Lake (fig. 1), was installed in 1910, and measurements were made for the water years 1910-12,1920-21, and 1930 through May 18, 1980. The station was destroyed by the May 18 mudflow. The average percentage of winter runoff to annual runoff for this station for the years prior to 1980 is 66 percent. This gage measured runoff for an area equal to 474 square miles, including Spirit Lake. Because much of this area is lower in altitude than that at Spirit Lake, the percentage of winter runoff to annual mean may be higher than that at Spirit Lake because some of the precipitation is stored as snow at the higher altitudes.

On the basis of records obtained at the long-term National Weather Service stations, precipitation during the winter season, averaged 90 and 122 percent of mean for the winter season of 1980-81 and 1981-82, respectively. Using these percentages and observed changes in volume of the lake during the two winters, and assuming a linear relationship between precipitation and runoff for this period, one can calculate that the change in lake volume that would correspond to winter mean precipitation would be approximately 43,700 acre-feet. Assuming that the increase in lake volume for the winter season represents 62 percent of the annual mean increase in lake volume, then total annual change in volume of Spirit Lake corresponding to annual mean precipitation is approximately 70,500 acre-feet.

Six precipitation gages were installed in the Spirit Lake watershed in September 1980. These gages do not record snowfall, however, and only provide data during the warmer periods of the year. These data are being collected as part of an effort to understand the overall rainfall-runoff characteristics of the Spirit Lake watershed.

Spirit Lake has not been instrumented for measurements to obtain evaporation rates. It was assumed that estimates of evaporation rates from regionalized data would be adequate for the purpose of this study.

Kohler and others (1959) indicate an average annual rate of water lost from a lake surface for the general area of Mount St. Helens equal to 24 inches. They also indicate that approximately 77 percent of this loss, or 18.5 inches, would occur between May and October. These estimates of evaporation rates, along with lake surface area, were used to estimate rates of water lost from the lake. As indicated by Kohler and others (1959), the reliability of the regionalized data is poor in areas of high relief, compared to the plain region. They also indicate that mountainous lakes in a canyon of northerly orientation shielded from the sun (a description that applies to the two arms of the lake) would experience considerably less evaporation than indicated by their work. Besides the fact that evaporation rates were determined from regionalized data, another complicating factor is the logs floating on the surface of Spirit Lake. The part of the lake containing floating logs varies, depending on the wind. The logs cover approximately 50 percent of the lake surface and would reduce overall evaporation losses from the lake. Figure 6a shows the relationship between lake level and lake area. Figure $6 \mathrm{~b}$ shows estimated annual rates of evaporation from the lake versus lake area, assuming an annual rate of loss equal to 24 inches. 


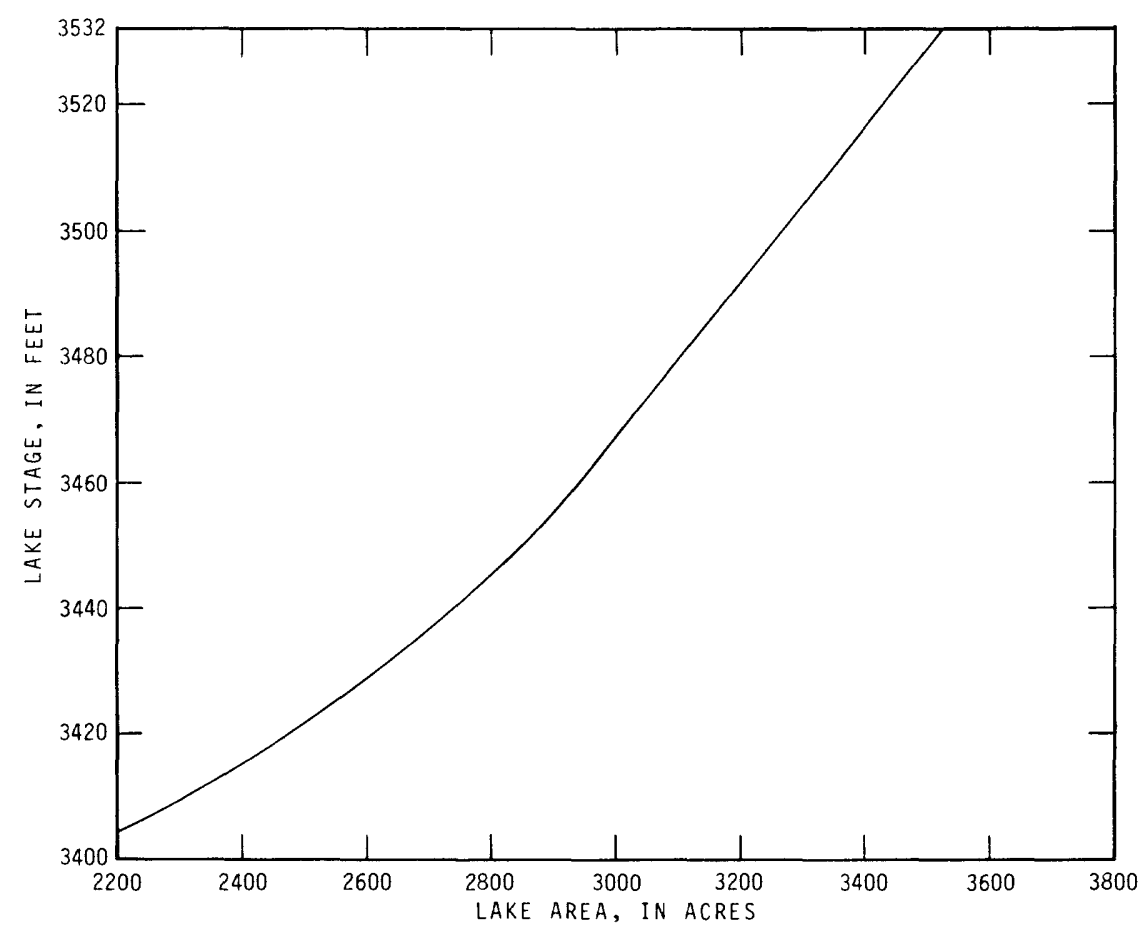

FIGURE 6a.--Relation of lake stage and lake area for Spirit Lake.

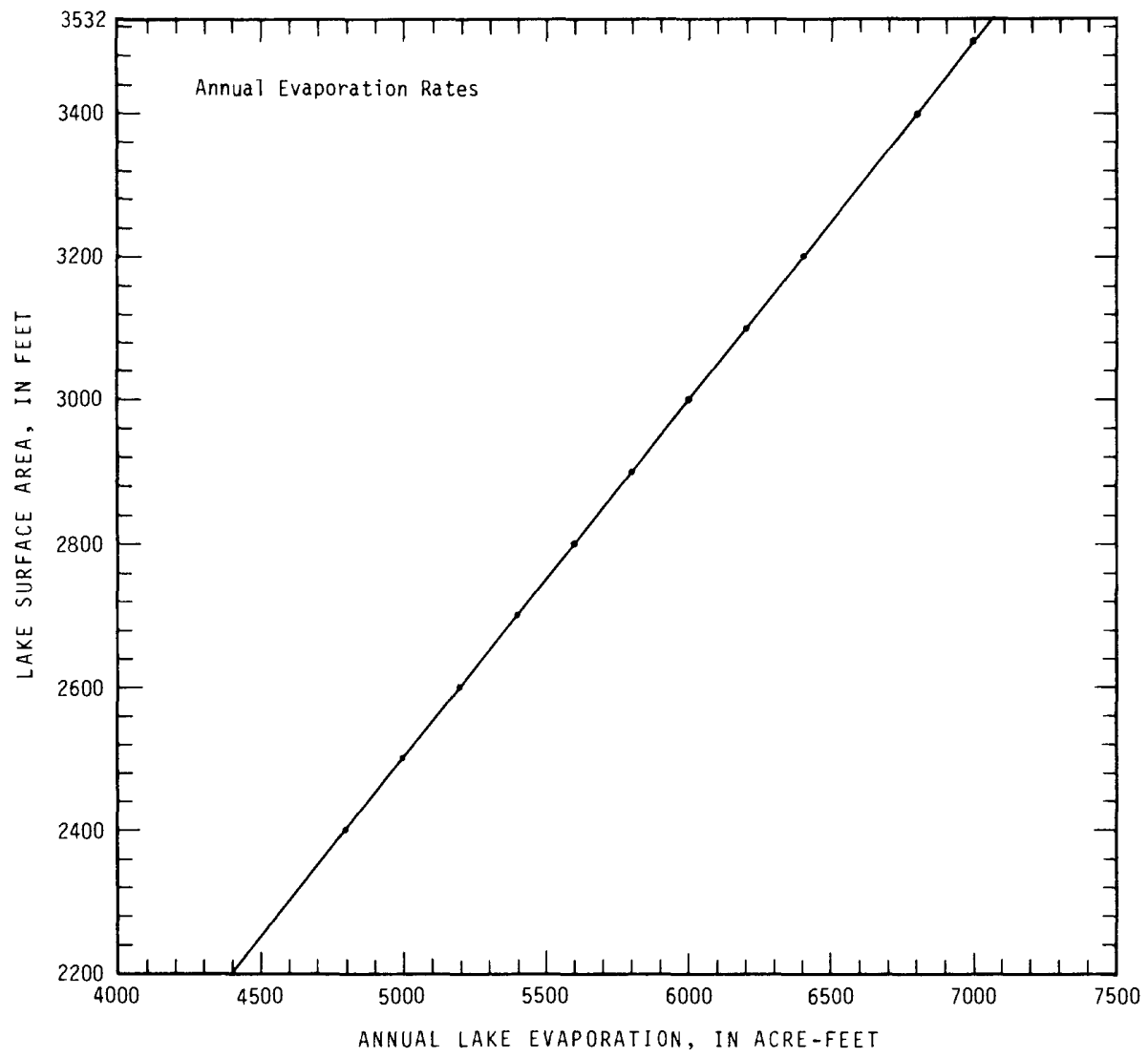

FIGURE 6b.--Relation of estimated annual evaporation and area for Spirit Lake. 


\section{Change in Lake Volume for Selected Time Periods}

Several other relationships between precipitation and change in lake volume are apparent for at least selected time periods from the available data. During August through September 8, 1981, when the lake volume basically stabilized and no precipitation occurred, one can write:

$$
\text { v/ } \begin{aligned}
\mathrm{t} & =\mathrm{P}+\mathrm{SM}+\mathrm{GWI}-(\mathrm{SA}+\mathrm{ET}+\mathrm{INF})-(\mathrm{LE}+\mathrm{LS}) \\
0 & =0+0+\mathrm{GWI}-(0+0+0)-(\mathrm{LE}+\mathrm{LS})
\end{aligned}
$$

or

$$
\mathrm{GWI}=\mathrm{LE}+\mathrm{LS}
$$

None of the processes in equation 2 were measured during this time period, but equation 2 indicates that GWI was occurring during this time and that it exceeded LS. This follows because LE can be assumed to be greater than zero.

From September 18-29, approximately 3,290 acre-feet of rainfall occurred on the Spirit Lake watershed and the lake gained 1,285 acre-feet in volume. Further, if it is assumed that the relationship expressed in equation 2 still existed during this time, then:

or

$$
\begin{aligned}
& v / t=p+S M+G W I-(S A+E T+I N F)-(L E+L S) \\
& 1285=3290+0+(L E+L S)-(0+E T+I N F)-(L E+L S)
\end{aligned}
$$

and

$$
\begin{aligned}
& \mathrm{P}-\mathrm{v} / \mathrm{t}=\mathrm{ET}+\mathrm{INF} \\
& \mathrm{ET}+\mathrm{INF}=60 \text { percent of precipitation }
\end{aligned}
$$

The amount or rate at which water infiltrates the land surface or evaporates from the surface for a given storm is a function of many variables, including rainfall duration, intensity, antecedent soil moisture, and intensity and duration of solar radiation. The above relationship, therefore, cannot be directly transferred to other precipitation periods. Analysis of data for a similar storm period during July 1982 resulted in $\mathrm{ET}+\mathrm{INF}$ equalling 48 percent of precipitation. 


\section{PROJECTED LAKE FILLING}

The ability of the lake to continue to fill and eventually overtop its debris dam and the time required for this to occur are major questions. If annual mean precipitation is assumed, then based on calculations in the preceeding section, lake volume would increase by approximately 70,500 acre-feet annually, unless those processes representing loss of water from the lake and (or) watershed increase or change to the point that their combined total exceeds their previous annual rates. As indicated, rates of water lost by either evapotranspiration or infiltration vary considerably and are dependent on many factors. Leavesley (written commun., 1982) has found that inflitration rates through ash deposits at an observation site in the Clearwater drainage (fig. 1), some 4 miles east of Spirit Lake, has increased with time since the eruption. If a similar process is occurring in the Spirit Lake drainage, one would expect less direct runoff for a given precipitation event, but on an annual basis the rate of change in volume gained by the lake would probably be insignificant, since most of the water that infiltrates can be assumed to reach the lake. If infiltration rates are increasing, some potential exists for less water loss by evaporation and an increase in the amount of water reaching the lake. The amount of water that could be potentially gained from reduced evaporation within the lake's watershed on an annual basis is believed to be small, however. The other processes that could potentially offset previously observed rates of annual growth in lake volume versus precipitation are lake evaporation and lake seepage.

Loss of water from the lake by evaporation will increase as the surface area of the lake increases. It is readily apparent from figure 5, however, that periods of maximum inflow to the lake correspond with periods when lake evaporation will be negligible. An annual increase in evaporation loss from the lake above the average annual rate for the preceeding year equal to 350 acre-feet was calculated assuming an increase in lake contents of 70,500 acre-feet over the next year. This increase in water lost is, of course, negligible compared to the projected increase in lake volume.

Loss of lake water by seepage into the debris dam may increase as the lake increases in size. Whether water is being lost or stored in this fashion is unclear at the present time. Ground-water mounds have existed since 1981 within the debris dams that blocks both Coldwater and South Fork Castle Lakes, and the existence of these mounds prevents loss of water by seepage from these lakes. Instead, ground water flows from these debris dams into the lakes. The Spirit Lake debris dam was checked during the summer of 1982 , for seepage faces at levels higher than lake level. None were found, and this tends to indicate that no ground-water mound exists in the dam at this time. 
A projection for the amount of lake filling during the next year was made assuming no increase in lake seepage for an increasing lake level (fig. 2). Unless a ground-water mound forms during the coming year on the debris dam or unless a highly permeable zone is reached by the rising lake water, this assumption should provide a reasonable estimate for the change in lake volume during the next year. On this basis and assuming annual mean precipitation, lake volume would increase to approximately 335,100 acre-feet by the end of July 1983 and lake stage would rise 24 feet. At this stage, the lake would still have 50 feet of freeboard between the existing low point on the crest of the debris dam.

If erosion lowers the crest of the debris dam during the year, available freeboard will, of course, be reduced. Channels 30-40 feet deep have been eroded on the debris dam over the last 2 years, although the crest of the dam has not yet been lowered. If a maximum 40 -foot reduction in the low point on the crest of the debris is assumed to occur by erosion during the coming year, available freeboard would be 10 feet at the end of July 1983. If precipitation during the next year is 1.5 times normal, lake stage will be 40 feet below the existing lowest point on the crest of the debris dam. Winter precipitation would have to be 2.3 times greater than winter mean for this same lake stage to be reached by the end of March 1983.

The lake will require approximately 3.4 years from August l, 1982, to fill to the existing low point on the crest of the debris dam for precipitation rates equal to annual mean, assuming seepage rates remain at the July 1982 rate as the lake level rises.

The preceding analysis indicates that considerable erosion of the low point on the crest of the debris dam or a combination of higher than normal precipitation and erosion will be required during the next year for Spirit Lake to represent an imminent flood hazard as a result of overtopping its dam. Work is presently underway to predict potential erosion rates on the dam and Iow areas of the crest of the debris will be watched closely during the coming year.

If a ground-water mound that blocks seepage from the lake forms in the debris during this coming year, the observed relationship between precipitation and change in lake volume could noticeably change, with filling rates increasing from those previously observed. Installation of observation wells is planned to begin in August 1982 , in order to determine ground-water levels in the debris dam. 
Kohler, M. A., Nordenson, T. J., and Fox, W. E., 1959, Evaporation map for the United States: U.S. Department of Commerce Weather Bureau Technical Paper No. 37,13 p. 5 plates.

Voight, Barry, Glicken, Harry, Janda, R. J., and Douglass, P. M. , 1981, Catastrophic rockslide avalanche of May 18: in Lipman, P. W., and Mullineaux, D. R., eds., The 1980 Eruptions of Mount St. Helens, Washington: U.S. Geological Survey Professional Paper 1250, p. 347-348.

Youd, T. L., Wilson, R. C., and Schuster, R. L., 1981, Stability of blockage in North Fork Toutle River: in Lipman, P. W., and Mullineaux, D. R., eds., The 1980 Eruptions of Mount St. Helens, Washington: U.S. Geological Survey Professional Paper 1250, p. 821-828. 